\title{
PENGEMBANGAN LKS DAN PENERAPANNYA DALAM PEMBELAJARAN KOOPERATIF TIPE STAD UNTUK MENINGKATKAN AKTIVITAS DAN HASIL BELAJAR KIMIA SISWA
}

\author{
Nur Azizah \\ Guru Kimia SMAN 1 Batulayar, Lombok Barat, Nusa Tenggara Barat. \\ Email: aziera.arkano@gmail.com
}

\begin{abstract}
Abstrak: Telah dilakukan penelitian tindakan kelas yang bertujuan untuk mengembangkan LKS dan menerapkannya dalam pembelajaran kooperatif tipe STAD (Student Teams Achievement Divisions) untuk meningkatkan hasil belajar materi kesetimbangan kimia siswa kelas XI IPA SMAN 1 Batulayar tahun pelajaran 2015/2016. Penelitian ini dilaksanakan dalam dua siklus. Siklus 1 dengan sub materi kesetimbangan dinamis, jenis kesetimbangan, dan tetapan kesetimbangan sedangkan siklus 2 dengan sub materi faktor-faktor yang mempengaruhi pergeseran kesetimbangan. Data dalam penelitian ini didapatkan melalui observasi, tes hasil belajar dan dokumentasi. Data hasil observasi aktivitas belajar siswa dianalisis dengan menghitung rata-rata skor aktivitas siswa sedangkan data hasil belajar dianalisis dengan menghitung nilai rata-rata siswa dan ketuntasannya secara klasikal. Hasil penelitian menunjukkan: 1) skor rata-rata aktivitas belajar siswa meningkat dari 19,83 menjadi 22,82 dengan kategori aktif, 2) hasil belajar siswa meningkat dari rata-rata 65 dengan ketuntasan klasikal 45,45\% menjadi 75 dengan ketuntasan klasikan 81,82\%.
\end{abstract}

Kata Kunci: LKS, Model Pembelajaran Kooperatif, Tipe STAD (Student Teams Achievement Divisions), AktivitasBelajar, Hasil Belajar.

\begin{abstract}
Classroom action research has been conducted to develop worksheets and apply them in cooperative learning STAD (Student Teams Achievement Divisions) to improve learning outcomes topic of chemical equilibrium class XI IPA SMAN 1 Batulayar in the academic year 2015/2016. This study was conducted in two cycles. The first cycle with the topic of dynamic equilibrium, the type of equilibrium, and the equilibrium constant. The second cycle with the topic of the factors that influence the equilibrium shifts. This research data obtained through observation, achievement test, and documentation. Data from observation of student activity was analyzed by calculating the average score of student activity while learning outcomes data were analyzed by calculating the average student and classical completeness. The results showed: 1) the average score of student activity increased (19.83 into 22.82) categorized as active, 2) student learning outcomes increased from an average of 65 with classical completeness $45.45 \%$ to 75 with classical completeness $81.82 \%$.
\end{abstract}

Keywords: Worksheet, Cooperative Learning Model, STAD (Student Teams Achievement Divisions), Learning Activity, Learning Outcomes.

\section{PENDAHULUAN}

Pendidikan itu bersifat mutlak dalam kehidupan bangsa dan negara. Maju mundurnya suatu negara tergantung dan ditentukan oleh maju mundurnya pendidikan di negara itu [1]. Oleh karenanya, dalam pembukaan Undang-Undang Dasar tahun 1945 diamanatkan bahwa Tujuan pendidikan nasional adalah untuk mencerdaskan kehidupan bangsa. Untuk mencapai tujuan itu, pemerintah selalu mengkaji dan memperbaiki berbagai jenis kurikulum yang telah diterapkan. Khususnya untuk pembelajaran kimia di setingkat Sekolah Menengah Atas adalah untuk melatih kemampuan berfikir logis, kritis, cermat dan tepat serta membekali siswa untuk dapat mempelajari ilmu pengetahuan dan teknologi pada jenjang sekolah lanjutannya, karena ilmu kimia merupakan dasar bagi ilmu-ilmu pengetahuan yang lain seperti, kedokteran, farmasi, geologi, maupun teknik [2].

Dalam pembelajaran kimia, umumnya siswa dilatih untuk dapat mengembangkan kemampuan dalam mengajukan gagasan-gagasan dan memupuk ketekunan serta ketelitian bekerja melalui penanaman metode ilmiah [2] sehingga siswa dapat menyelesaikan permasalahan kimia dengan benar dan cepat. Kondisi ini menyebabkan siswa hanya memiliki kemampuan teknis dalam menyelesaikan permasalahan kimia tanpa memahami apa sebenarnya yang diselesaikan dan apa manfaat penyelesainnya. Pada umumnya, siswa memiliki pandangan bahwa hasil kerja dalam pembelajaran kimia hanya berupa hasil tes untuk memenuhi syarat kenaikan kelas/kelulusan saja. Padahal hasil belajar kimia yang diharapkan adalah siswa memiliki keterampilanketerampilan proses sains yang akan menjadi penggerak penemuan dan pengembangan fakta dan konsep serta penumbuhan dan pengembangan sikap, wawasan, dan nilai tanpa harus menguasai fakta dan konsep yang terhimpun dalam ilmu kimia [2].

Menurut Johnson dan Smith (1991) dalam Lie [3] pendidikan merupakan interaksi pribadi di antara para siswa dan di antara guru dan siswa. Kegiatan pendidikan adalah suatu proses sosial yang terjadi ketika masing-masing orang berhubungan dengan orang lain dan membangun pengertian serta pengetahuan bersama. Khususnya dalam pembelajran 
kimia proses di atas dimaksudkan agar siswa berperan aktif dalam kegiatan pembelajaran agar terlatih untuk meningkatkan daya berfikirnya (logika) untuk dapat menemukan sendiri konsep dasar dari materi yang sedang dipelajari. Namun pada kenyataannya, siswa seringkali mengalami kesulitan untuk dapat menemukan konsep sendiri sehingga guru kerap kali mendominasi kelas dalam proses belajar mengajar. Dengan kata lain, proses pembelajaran lebih terpusat pada guru (teacher centered). Kondisi ini menyebabkan siswa hanya menghafal konsep bukan memahaminya sehingga akan berdampak terhadap perolehan hasil belajar siswa yang tidak sesuai dengan yang diharapkan.

Rendahnya hasil belajar siswa masih menjadi kendala yang sangat besar bagi dunia pendidikan terutama bagi sekolah-sekolah yang masih mengalami masa perkembangan, khususnya SMAN 1 Batulayar. Rendahnya hasil belajar siswa juga terjadi pada mata pelajaran kimia khususnya pada materi pokok kesetimbangan kimia. Hal tersebut terlihat dari nilai hasil belajar yang tercatat pada tiga tahun terakhir rata-rata nilainya rendah $(66,44)$, ketuntasan klasikal (rata-rata 55,56\%) juga belum tercapai karena jumlah siswa yang tuntas secara perorangan belum mencapai $75 \%$.

Berdasarkan hasil refleksi, belum maksimalnya hasil belajar siswa tersebut diakibatkan oleh :

1) Aktivitas belajar siswa yang masih rendah, hal tersebut dapat disebabkan karena rendahnya minat siswa dalam belajar sehingga siswa menjadi kurang tertarik untuk belajar yang mengakibatkan siswa menjadi cenderung pasif dan mengandalkan guru sebagai satu-satunya sumber belajar.

2) Metode mengajar yang digunakan oleh guru yaitu ceramah dan tanya jawab. Metode ceramah memiliki kelemahan diantaranya akan terasa sulit bagi siswa yang memiliki kemampuan menyimak dan mencatat kurang baik, kurang memberikan kesempatan kepada siswa untuk berpartisi secara total dalam pembelajaran, materi pelajaran cenderang pada aspek ingatan, proses pembelajaran berada dalam otoritas guru sehingga guru yang mendominasi dalam proses pembelajaran. Sedangkan metode tanya jawab membuat siswa sering merasa takut untuk mendapat pertanyaan guru, waktu sering banyak terbuang terutama apabila siswa tidak dapat menjawab pertanyaan sehingga guru masih tetap mendominasi pembelajaran [4].

Karso [5] menyatakan bahwa "salah satu upaya untuk meningkatkan mutu pendidikan adalah dengan meningkatkan pembelajaran yaitu dengan cara menerapkan strategi pembelajaran yang lebih efektif'. Khususnya dalam pembelajaran kimia, Strategi yang diperlukan di sini adalah sebuah strategi belajar baru yang lebih memberdayakan siswa dan tidak mengharuskan siswa menghafal fakta-fakta, akan tetapi sebuah strategi yang mendorong siswa untuk mengkonstruksikan pengetahuan di benak mereka sendiri .

Mencermati keadaan tersebut, khususnya dalam materi kestimbangan kimia, diantara alternatif solusi yang dapat diambil adalah dengan merubah strategi pembelajaran yaitu dengan mengembangkan media LKS (Lembar Kerja Siswa) dan menerapkan model pembelajaran yang berpusat kepada siswa yaitu pembelajaran kooperatif tipe STAD (Student Teams Achievement Divisions) [6-9]. STAD merupakan salah satu model pembelajaran kooperatif dengan menggunakan kelompok kecil (4-5 orang) secara heterogen. Diawali dengan penyampaian tujuan pembelajaran, penyampaian materi, kegiatan kelompok, kuis, dan penghargaan kelompok [10]. Dengan mengerjakan permasalahan yang terdapat dalam LKS melalui langkah-langkah dalam pembelajaran kooperatif tipe STAD tersebut akan merangsang siswa untuk meningkatkan daya fikirnya (logika) kemudian mengunakannya dalam menyelesaikan masalah.. Dengan bantuan bimbingan guru, akan dapat memberikan dampak kepada kemampuan siswa untuk melatih daya fikirnya (logika), sehingga diharapkan siswa akan dapat menemukan sendiri konsep dasar dari materi kesetimbangan kimia. Oleh karena itu, suatu tindakan (action) dari konsep tersebut perlu diimplementasikan dalam kegiatan pembelajaran.

Berdasarkan uraian di atas, maka permasalahan dalam penelitian ini adalah bagaimanakah pengembangan LKS dan hasil penerapannya dalam pembelajaran kooperatif tipe STAD pada materi kesetimbangan kimia terhadap peningkatan aktivitas dan hasil belajar siswa kelas XI IPA SMAN 1 Batulayar tahun pelajaran 2015/2016.

\section{METODE PENELITIAN}

Penelitian ini merupakan penelitian tindakan kelas (Classroom Action Research). Penelitian tindakan kelas merupakan suatu pencermatan terhadap kegiatan belajar berupa sebuah tindakan, yang sengaja dimunculkan dan terjadi dalam sebuah kelas secara bersama [11]. Penelitian ini menggunakan pendekatan kuantatif dan kualitatif. Pendekatan kuantitatif digunakan untuk mendapatkan data tentang hasil belajar, sedangkan pendekatan kulitatif digunakan untuk mendapatkan data tentang aktivitas belajar siswa. Penelitian ini dilaksanakan di kelas XI IPA SMAN 1 Batulayar Jl. Raya Senggigi Km. 5 Desa Senteluk Kab. Lombok Barat pada semester 1 Tahun Pelajaran 2015/2016. Adapun yang menjadi variabel harapan dalam penelitian ini adalah peningkatan aktivitas belajar dan hasil belajar siswa dan variabel tindakan-nya adalah pengembangan LKS dan penerapannya dalam pembelajaran kooperatif tipe STAD.

Penelitian ini dirancang dalam dua siklus, dan setiap siklus terdiri dari beberapa tahapan. Ada beberapa ahli yang mengemukakan model penelitian tindakan dengan bagan yang berbeda, namun secara 
garis besar terdapat empat tahapan yang lazim dilalui yaitu (1) Perencanaan (2) Pelaksanaan (3) Pengamatan (Observasi) (4) Refleksi [11].

Data dalam penelitian ini dikumpulkan melalui observasi dan tes hasil belajar pada tiap-tiap siklusnya. Observasi dilakukan untuk mengetahui peningkatan aktivitas belajar siswa sedangkan tes hasil belajar digunakan untuk mengetahui peningkatan hasil belajar siswa. Pada tahap refleksi dilakukan analisis mengenai proses pembelajaran, masalah dan hambatan untuk dilakukan perbaikan pada siklus berikutnya.

\section{HASIL PENELITIAN}

\section{1) Data Hasil Observasi Aktivitas Siswa}

Aktivitas siswa diamati berdasarkan indikator dan deskriptor yang terdapat dalam lembar observasi seperti yang telah dirancang sebelumnya. Data observasi siswa yang diperoleh pada siklus 1 adalah rata-rata skor aktivitas siswa sebesar 19,67 dari observer 1 dan 19,99 dari observer 2 sehingga diperoleh rata-rata skor aktivitas siswa 19,83. Skor rata-rata tersebut termasuk aktivitas belajar siswa dalam kategori aktif. Sedangkan pada siklus 2 diperoleh rata-rata skor aktivitas siswa dari observer 1 sebesar 22,66 dan observer 2 sebesar 22,98 sehinngga rata-rata skor siswa meningkat 22,82. Skor rata-rata tersebut termasuk aktivitas belajar siswa dalam kategori aktif. Data aktivitas siswa dapat dilihat pada Tabel 1 berikut :

Tabel 1. Data Aktivitas Belajar Siswa

\begin{tabular}{lcc}
\hline $\begin{array}{c}\text { Aktivitas } \\
\text { Belajar Siswa }\end{array}$ & Siklus 1 & Siklus 2 \\
\hline Rata-rata skor & 19,83 & 22,82 \\
\hline Kategori & Aktif & Aktif \\
\hline
\end{tabular}

\section{2) Data Hasil Observasi Aktivitas Guru}

Aktivitas guru dalam menyampaikan pelajaran diamati berdasarkan indikator dan deskriptor yang terdapat dalam lembar observasi seperti yang telah dirancang sebelumnya. Data observasi guru yang diperoleh pada siklus 1 adalah jumlah skor aktivitas guru sebesar 18 dari observer 1 dan 16 dari observer 2 sehingga diperoleh rata-rata skor aktivitas guru sebesar 17. Skor rata-rata tersebut termasuk aktivitas guru dalam kategori aktif. Sedangkan pada siklus 2 diperoleh skor aktivitas guru sebersar 19 dari observer 1 dan 20 dari observer 2 , sehingga rata-rata skor aktivitas guru meningkat menjadi 19,5. Skor rata-rata tersebut termasuk aktivitas guru dalam kategori aktif. Data aktivitas guru dapat dilihat pada Tabel 2.

Tabel 2. Data Aktivitas Guru

\begin{tabular}{lll}
\hline Aktivitas Guru & Siklus 1 & Siklus 2 \\
\hline
\end{tabular}

\begin{tabular}{ccc}
\hline Jumlah skor & 18 & 19 \\
\hline Kategori & Aktif & $\begin{array}{c}\text { Sangat } \\
\text { Aktif }\end{array}$ \\
\hline
\end{tabular}

\section{3) Data Hasil Belajar Siswa}

Data hasil belajar siswa diperoleh dari hasil evaluasi yang dilakukan pada akhir tiap-tiap siklus. Tes hasil belajar dilakukan untuk mengetahui ketuntasan siswa dalam belajar baik individual maupun klasikal. Pada siklus 1 diperoleh data hasil belajar dengan nilai tertinggi 80 , nilai terendah 50 , nilai rata-rata 65 dan ketuntasan klasikal 45,45\%. Pada siklus 1 ini ketuntasan klasikal tidak tercapai karena kurang dari $75 \%$ siswa yang mencapai/melampaui KKM (nilai $\geq 70$ ). Sedangkan siklus 2 diperoleh data hasil belajar dengan nilai tertinggi 100, nilai terendah 50, nilai rata-rata 75 dan ketuntasan klasikal $81,82 \%$. Pada siklus 2 ketunasan klasikal tercapai karena lebih dari $75 \%$ siswa telah mencapai/melampaui KKM (nilai $\geq 70$ ). Rekapitulasi data hasil belajar siswa dapat dilihat pada Tabel 3 berikut.

Tabel 3. Rekapitulasi Hasil Belajar Siswa

\begin{tabular}{lcc}
\hline Nilai & Siklus 1 & Siklus 2 \\
\hline Tertinggi & 80 & 100 \\
\hline Terendah & 50 & 50 \\
\hline Rata-rata & 65 & 75 \\
\hline Ketuntasan Klasikal & $45,45 \%$ & $81,82 \%$ \\
\hline
\end{tabular}

\section{PEMBAHASAN}

\section{1) Siklus 1}

Siklus 1 berlangsung selama 3 x 45 menit dalam satu kali pertemuan. Materi yang diajarkan dalam proses pembelajaran ini adalah kesetimbangan dinamis, jenis kesetimbangan dan tetapan kesetimbangan. Materi disajikan dalam bentuk LKS, diskusi, presentasi.

Dari hasil observasi selama siklus 1 didapatkan rata-rata skor aktivitas siswa pada pembelajaran adalah 19,83 dimana skor tersebut termasuk dalam kategori aktif (Tabel 2). Sedangkan aktivitas guru didapatkan rata-rata skor 17 dimana skor tersebut termasuk dalam kategori aktif juga (tabel 3). Sedangkan untuk hasil belajar didapatkan nilai rata-rata kelas 65 dan ketuntasan klasikal 45,45\% (tabel 3). Dari angka ketuntasan tersebut terlihat bahwa ketuntasan klasikal belum tercapai karena masih kurang dari $75 \%$ siswa yang mencapai ketuntasan secara individual (mendapatkan nilai $\geq 70$ ). Hal tersebut merupakan dampak dari aktivitas siswa dan guru pada proses pembelajaranyang kurang maksimal pada proses pembelajaran.

Menurut Hamalik [8] pembelajaran yang efektif adalah pembelajaran yang menyediakan kesempatan kepada siswa untuk dapat belajar sendiri atau melakukan aktivitas sendiri dimana dalam 
aktivitasnya mereka belajar sambil bekerja. Oleh karenanya walaupun aktivitas dari siswa dan guru termasuk dalam kategori aktif, namun ada beberapa hal yang menjadi temuan dalam kegiatan refleksi pembelajaran pada siklus 1 yang memerlukan perbaikan untuk diterapkan pada siklus berikutnya.

Adapun temuan-temuan dalam kegiatan refleksi proses pembelajaran pada siklus 1 dirangkum dalam Tabel 4 berikut :

Tabel 4. Hasil Refleksi Proses Pembelajaran Siklus 1

\begin{tabular}{|c|c|c|}
\hline Temuan & Penyebab & Solusi \\
\hline $\begin{array}{l}\text { Siswa kurang berani dalam } \\
\text { mengajukan pertanyaan kepada } \\
\text { guru }\end{array}$ & Siswa merasa malu & $\begin{array}{l}\text { Guru memberi arahan dan memotivasi } \\
\text { siswa agar lebih berani bertanya dan } \\
\text { menyampaikan kesulitannya dalam } \\
\text { mengerjakan tugas yang diberikan oleh } \\
\text { guru. }\end{array}$ \\
\hline $\begin{array}{l}\text { Siswa kurang aktif dalam } \\
\text { kegiatan diskusi }\end{array}$ & Siswa belum sarapan & $\begin{array}{l}\text { Guru memberikan teguran dan motivasi } \\
\text { kepada siswa agar memperhatikan } \\
\text { kebutuhan fisik dan mentalnya sehingga } \\
\text { lebih aktif melibatkan diri dalam diskusi } \\
\text { kelompok. }\end{array}$ \\
\hline $\begin{array}{l}\text { Siswa masih sangat bergantung } \\
\text { pada bimbingan guru dalam } \\
\text { menyelesaikan tugas dalam LKS. }\end{array}$ & $\begin{array}{l}\text { Siswa kurang dalam membaca } \\
\text { uraian materi yang dicantumkan } \\
\text { dalam LKS. }\end{array}$ & $\begin{array}{l}\text { Guru mengarahkan dan memotivasi siswa } \\
\text { agar selalu membaca terlebih dahulu } \\
\text { sebelum menanyakannya kepada guru }\end{array}$ \\
\hline $\begin{array}{l}\text { Siswa kesuliatan dalam } \\
\text { menyimpulakn materi yang } \\
\text { sudah selesai dibahas }\end{array}$ & $\begin{array}{l}\text { Siswa tidak kurang } \\
\text { memperhatikan ketika guru } \\
\text { memberikan penjelasan. }\end{array}$ & $\begin{array}{l}\text { Guru membantu siswa yang masih } \\
\text { kesulitan dalam menyimpulkan materi } \\
\text { yang sudah dibahas. }\end{array}$ \\
\hline $\begin{array}{l}\text { Siswa kurang partisipatif dalam } \\
\text { menyimpulkan materi pembe- } \\
\text { lajaran }\end{array}$ & $\begin{array}{l}\text { Siswa kurang mampu } \\
\text { berkomunikasi dengan baik }\end{array}$ & $\begin{array}{l}\text { Guru membantu siswa untuk bisa } \\
\text { mengkomu-nikasikan kesimpulan yang } \\
\text { telah dibuat. }\end{array}$ \\
\hline $\begin{array}{l}\text { Guru tidak menyampaikan } \\
\text { tujuan pembelajaran. }\end{array}$ & $\begin{array}{l}\text { Guru fokus menyampaikan } \\
\text { materi pokok yang akan dibahas }\end{array}$ & $\begin{array}{l}\text { Guru akan menyampaikan tujuan } \\
\text { pembelajaran pada siklus berikutnya. }\end{array}$ \\
\hline $\begin{array}{l}\text { Guru kurang memberikan } \\
\text { bimbingan merata secara } \\
\text { perorangan. }\end{array}$ & $\begin{array}{l}\text { Guru fokus member bimbingan } \\
\text { pada siswa yang telah bertanya } \\
\text { lebih dahulu }\end{array}$ & $\begin{array}{l}\text { Guru hendaknya memberikan bimbingan } \\
\text { yang merata baik secara perorangan } \\
\text { maupun kelompok. }\end{array}$ \\
\hline $\begin{array}{l}\text { Guru kurang membimbing } \\
\text { dalam membuat kesimpulan } \\
\text { dengan bahasanya sendiri }\end{array}$ & $\begin{array}{l}\text { Guru kurang mmpu } \\
\text { mengkondisikan siswa yang } \\
\text { ribut karena melihat kelas lain } \\
\text { sudah keluar istirahat. }\end{array}$ & $\begin{array}{l}\text { Guru hendaknya mengkondisikan siswa } \\
\text { yang ribut dan membimbing siswa dalam } \\
\text { membuat kesimpulan dengan bahasanya } \\
\text { sendiri. }\end{array}$ \\
\hline $\begin{array}{l}\text { Guru kurang memberikan waktu } \\
\text { tunggu kepada siswa dalam } \\
\text { mengerjakan soal post test }\end{array}$ & $\begin{array}{l}\text { Guru kurang mmpu } \\
\text { mengkondisikan siswa yang } \\
\text { ribut karena melihat kelas lain } \\
\text { sudah keluar istirahat. }\end{array}$ & $\begin{array}{l}\text { Guru hendaknya lebih bisa mengelola } \\
\text { waktu dalam pembelajaran agar sesuai } \\
\text { dengan skenario pembelajaran yang telah } \\
\text { direncanakan. }\end{array}$ \\
\hline
\end{tabular}

\section{2) Siklus 2}

Siklus 2 berlangsung selama 3 x 45 menit dalam satu kali pertemuan. Materi yang diajarkan dalam proses pembelajaran siklus 2 ini adalah factorfaktor yang mempengaruhi kesetimbangan. Materi disajikan dalam bentuk LKS, diskusi, presentasi.

Berdasarkan temuan-temuan pada kegiatan refleksi siklus 1, maka pada siklus 2 dilakukan perbaikan-perbaikan sesuai dengan solusi yang telah disepakati pada saat refleksi (Tabel 4). Dari hasil observasi selama siklus 2 didapatkan rata-rata skor aktivitas siswa pada pembelajaran adalah 22,82 dimana skor tersebut termasuk dalam kategori aktif (Tabel 1). Dari data pada tabel 2 terlihat terjadi peningkatan skor yang cukup sigifikan dari siklus 1 yang menandakan aktivitas siswa mengalami peningkatan walaupun memiliki kategori yang sama yaitu aktif.

Sedangkan dari hasil observasi untuk aktivitas guru didapatkan rata-rata skor 19 dimana skor tersebut termasuk dalam kategori sangat aktif (tabel 3). Seperti halnya aktivitas siswa, aktivitas guru juga mengalami peningkatan skor yaitu dari 17 menjadi 19 dengan predikat aktif pada siklus 1 menjadi predikat sangat aktif pada siklus 2 .

Analisis untuk hasil belajar siswa pada siklus 2 didapatkan nilai rata-rata kelas meningkat dari sebelumnya 65 menjadi 75. Sedangkan untuk ketuntasan klasikal pada siklus 2 ini mencapai 81,82\% (Tabel 3). Dari angka ketuntasan tersebut terlihat bahwa ketuntasan klasikal sudah tercapai lebih dari $75 \%$ siswa yang mencapai ketuntasan secara individual (mendapatkan $\geq 70$ ). Dengan kata 
lain indikator kriteria keberhasilan tindakan dalam penelitian ini telah dapat dicapai pada siklus 2 .

Walaupun hasil belajar siswa dari siklus 1 ke siklus 2 mengalami peningkatan, namun peningkatan tersebut belum maksimal karena siswa hanya mencapai nilai rata-rata kelas 75 . Hal tersebut menunjukkan bahwa penggunaan dan penerapan suatu model/metode pembelajaran bukan menjadi satu-satunya faktor penentu hasil belajar siswa. Menurut Muhibbinsyah [12] faktor-faktor yang mempengaruhi hasil belajar adalah: a) Faktor Internal, yaitu faktor yang berasal dari dalam diri siswa seperti halnya minat, bakat dan kemampuan, b) Faktor Eksternal yaitu faktor yang berasal dari lingkungan siswa seperti keadaan keluarga, latar belakang ekonomi dan kemampuan guru dalam mengajar. Oleh karenanya sangat perlu untuk memperhatikan faktor- faktor tersebut seperti yang terjadi pada siklus 1, siswa kurang aktif dalam kegiatan diskusi karena siswa belum sarapan (lapar).

\section{KESIMPULAN}

Hasil penelitian menunjukkan: 1) skor rata-rata aktivitas belajar siswa meningkat dari 19,83 menjadi 22,82 dengan kategori aktif, 2) hasil belajar siswa meningkat dari rata-rata 65 dengan ketuntasan klasikal 45,45\% menjadi 75 dengan ketuntasan klasikan $81,82 \%$. Berdasarkan hasil penelitaian dan pembahasan dapat disimpulkan bahwa LKS hasil pengembangan dan penerapannya dalam pembelajaran kooperatif tipe STAD dapat meningkatkan aktifitas dan hasil belajar materi kesetimbangan kimia pada siswa kelas XI IPA SMAN 1 Batulayar tahun pelajaran 2015/2016.

\section{DAFTAR PUSTAKA}

[1]. Indra, Kusuma, A. D. 1973. Pengantar Ilmu Pendidikan. Surabaya: Usaha Nasional.

[2]. Depdiknas, 2007. Petunjuk Teknis Pengembangan Silabus dan Contoh/Model Silabus SMA/MA Mata Pelajaran Kimia. Penyelenggaraan Sosialisasi/Diseminasi/ Workshop/Publikasi. Direktorat Jenderal Manajemen Pendidikan Dasar dan Menengah.

[3]. Lie, A. 2002. Cooperative Learning. Jakarta: PT Gramedia Widia Sarana.

[4]. Sudirman, 1992. Kelebihan \& Kelemahan Metode Tanya Jawab. Online. Http://Faizalnizbah.blogspot.co.id/2013/08/keleb ihan-dan-kelemahan-metode-tanya.html?m=1. Diakses tanggal 2 Desember 2015.

[5]. Karso, 1995. Dasar-dasar Pendidikan MIPA. Universitas Terbuka, Depdikbud, Jakarta, modul 1-6.
[6]. Aryana, I. G. M. R., Al Idrus, A., \& Harjono, A. (2015). Pengaruh model pembelajaran kooperatif nht dan stad terhadap hasil belajar sikap siswa sma negeri 2 gerung. Jurnal pijar MIPA, 10(2).

[7]. Raksun, A. (2009). Implementasi pembelajaran kooperatif untuk meningkatkan motivasi dan hasil belajar mahasiswa program studi pendidikan fisika fkip universitas mataram pada matakuliah biologi dasar. Jurnal pijar MIPA, $4(1)$.

[8]. Yulianti, R., Muntari, M., \& Haris, M. (2015). Pengaruh model pembelajaran kooperatif tipe two stay two stray (tsts) dengan pendekatan brain-based learning terhadap hasil belajar kimia materi pokok struktur atom dan sistem periodik unsur pada siswa kelas x sman 1 kediri. Jurnal pijar MIPA, 10(1).

[9]. Hirzi, R. H., Sripatmi, S., \& Hapipi, H. (2015). Penerapan model pembelajaran kooperatif tipe snowball throwing pada pembelajaran segiempat untuk meningkatkan aktivitas dan prestasi belajar siswa smpn 1 lingsar kelas vii-1 tahun pelajaran 2012/2013. Jurnal pijar MIPA, 10(1).

[10]. Mardianto, 20013. Model, Pendekatan, Strategi, Metode, Tekni, Taktik, dan Desain Pembelajaran. Disajikan pada kegiatan:MGMP Kimia Kabupaten Lombok Barat: 21 Februari 2013 di Gerung Lombok Barat.

[11]. Suharsimi,dkk. 2009. Penelitian Tindakan Kelas. Jakarta: Bumi Aksara.

[12]. Hamalik,Oemar.2011.Proses Belajar Mengajar. Jakarta: Bumi Aksara

[13]. Muhibbinsyah, 2004. Psikologi Belajar. Jakarta: PT Raja Grafindo. 